\title{
Implementasi Pengolahan Citra Digital Sebagai Pengukur Nilai Resistor Pada Sistem Pemindai Resistor Berbasis Android
}

\author{
Satrio Firmansyah* ${ }^{1}$, Danang Lelono ${ }^{2}$, Raden Sumiharto ${ }^{3}$ \\ ${ }^{1}$ Prodi Elektronika dan Instrumentasi Jurusan Ilmu Komputer dan Elektronika, FMIPA UGM \\ ${ }^{2,3}$ Jurusan Ilmu Komputer dan Elektronika, FMIPA UGM \\ e-mail: *11 ryotakaba@@gmail.com, ${ }^{2}$ danang@ugm.ac.id, ${ }^{3}$ mmx_77@yahoo.com
}

\begin{abstract}
Abstrak
Salah satu gadget yang sering digunakan adalah telepon pintar berbasis Android. Android bersifat Open Source sehingga memungkinkan pengguna dan pengembang dalam mengoperasikan maupun membuat aplikasi berbasis Android. Ada berbagai macam permasalahan yang membutuhkan citra sebagai masukan atau input sistem dikarenakan keterbatasan manusia dalam hal kecepatan memproses suatu fungsi matematis maupun algoritma pendukung didalamnya, selain itu juga masalah waktu dan lain sebagainya. Salah satu sistem yang membutuhkan citra sebagai masukannya adalah penentuan nilai resistor berdasarkan gelang warna. Untuk melakukan seleksi warna digunakan metode segmentasi warna pemodelan warna HSV. Dengan menggunakan model warna HSV dapat menjadi model warna yg dapat digunakan sebuah sistem untuk menentukan nilai warna resistor, karena komponen nilai hue adalah representasi dari nilai warna yang sebenarnya. Hal ini didukung dengan saturation yang berfungsi sebagai tingkat kejenuhan suatu warna dan nilai value sebagai nilai kecerahan warna. Uji coba sistem dilakukan dengan pengujian pengaruh intensitas cahaya dan jarak pendeteksian antara kamera dan resistor.

Hasil dari penelitian ini berupa sebuah implementasi pengolahan citra digital sebagai pengukur nilai resistor. Hasil terbaik dicapai dengan kondisi ruangan pada intensitas cahaya lampu antara 400 lux hingga 1200 lux dengan jarak pendeteksian antar kamera dan resistor yaitu maksimal $20 \mathrm{~cm}$.
\end{abstract}

Kata kunci- pengolahan citra digital, Android, resistor, HSV, intensitas cahaya, java

\begin{abstract}
One of the gadget that is often used is Android smart phones. Android is an OpenSource, it could help user and developer to operate and develop Android Application. There are several problems that need image as an input system, it is caused by the humas's ability in doing some mathematic functions or supported algorythm. To make the selection color used HSV color space. By using HSV color space allows a system to determine the color value resistor, because the hue value of the component is a representation of the actual color value. This is supported by the saturation level that serves as a color saturation and value as a brightness of color.

The results of this research is an implementation of digital image processing as a measure of the value of the resistor. The system is tested by the influence of light intensity and the distance between the camera and resistor. The best results were achieved with the conditions of the room in light intensity between 400 lux to 1200 lux the detection distance between the camera and resistor is $20 \mathrm{~cm}$ of maximum value.
\end{abstract}

Keywords — digital image processing, Android, resitor, HSV, light intensity, java 


\section{PENDAHULUAN}

$\mathrm{C}$ itra atau gambar merupakan salah satu komponen penting dalam dunia multimedia karena memiliki peranan penting dalam hal menyajikan suatu informasi dalam bentuk gambar atau visual. Penyajian informasi dalam bentuk citra atau gambar dapat memberikan manfaat yang lebih dan dapat menggantikan informasi yang berupa teks atau tulisan.[1] Ada berbagai macam permasalahan yang membutuhkan citra sebagai masukan atau input sistem dikarenakan keterbatasan manusia dalam memproses suatu fungsi matematis maupun algoritma pendukung didalamnya. Salah satu sistem yang membutuhkan citra sebagai masukannya adalah penentuan nilai resistor berdasarkan gelang warna. Dalam dunia elektronika dikenal resistor yang merupakan salah satu komponen-komponen dasar elektronika yang berfungsi sebagai penghambat aliran arus listrik, pembagi arus, penurun tegangan dan lain-lain.[2]Tidak semua orang dapat menghitung nilai resistor dengan tepat, baik itu ketepatan dalam membaca warna maupun ketepatan dalam proses kalkulasi matematis. Dalam menentukan nilai warna resistor diperlukan algoritma pemrograman yang mampu menganalisa dan mengenali warna yang terdapat dalam objek citra atau gambar sesuai dengan warna-warna yang terdapat dalam tabel warna resistor.

Perkembangan teknologi saat ini memiliki kemajuan yang cukup pesat. Dalam hal ini khususnya gadget yang memiliki berbagai macam kemampuan dalam membantu segala aktivitas-aktivitas manusia dalam kehidupan sehari-hari. Salah satu gadget yang sering digunakan adalah telepon pintar. Telepon pintar dapat didefinisikan sebagai telepon yang memiliki kemampuan tingkat tinggi yang menyerupai komputer, hal ini membuat pengguna tidak hanya menerima panggilan atau sms, tapi juga dapat menyediakan berbagai macam fiturfitur seperti internet dan menyediakan kebutuhan lain bagi pengguna maupun pengembang aplikasi. Dalam penelitian ini akan membuat sebuah program aplikasi berbasis android yang mampu melakukan pembacaan nilai resistor sebagai alat bantu. Sistem ini bekerja langsung dengan menggunakan handphone berkamera yang cukup praktis bisa dibawa kemana-mana dengan cara langsung menghadapkan kamera tepat pada resistor dengan hasil nilai resistor yang langsung bisa diketahui pada layar handphone. Dalam hal ini pemindai resistor bekerja dengan memanfaatkan teknologi image processing..

Dalam pemrograman untuk melakukan seleksi warna, diperlukan berbagai macam teknik pengolahan citra digital seperti thresholding, segmentasi dan berbagai macam model warna.[3] Model warna yang dapat digunakan adalah model warna HSV (hue, saturation \& value). Dengan menggunakan model warna HSV memungkinkan sebuah sistem untuk menentukan nilai warna resistor.[4] Banyak penelitian yang sudah dilakukan menggunakan pemodelan ini namun batas-batas warna yang diberikan masih banyak yang kurang tepat.

\section{METODE PENELITIAN}

\subsection{Analisis Sistem}

Sistem yang dibuat merupakan sebuah sistem pemindai resistor dengan memanfaatkan pengolahan citra digital sebagai pengukur nilai resistor yang diimplementasikan pada gadget yang memiliki platform Android. Pemindai resistor ini berfungsi untuk mengukur nilai resistor dengan cara mengetahui gelang-gelang warna yang terdapat pada resistor. Warna-warna yang terdapat pada resistor menunjukkan nilai dari resistor.

\subsection{Perancangan Sistem}

Gambar 1 merupakan gambar blok diagram sistem keseluruhan. Pada sistem pemindai resistor ini terdiri dari 2 proses yakni proses deteksi warna dan kontur dan proses kalkulasi nilai resistor.

IJEIS Vol. 5, No. 1, April $2015: 1$ - 10 
Pada bagian program pendeteksian warna dan kontur terdapat beberapa proses dimulai dari awal ketika aplikasi mulai berjalan. Diawali dengan kamera ketika hidup yang langsung diarahkan tepat ke resistor. Setelah user menekan tombol mulai scan maka sistem akan langsung otomatis melakukan proses scanning warna secara berurutan dimulai dari warna hitam, coklat, merah, jingga, kuning, hijau, biru dan ungu dan kamera akan langsung mencari warna sesuai dengan segmentasi atau batas warna yang telah diberikan dalam skala HSV pada masing-masing warna yang ada dalam satu frame tersebut. Dalam hal ini input sistem berupa citra warna yang ditangkap oleh kamera dalam bentuk sebuah frame. Pendeteksian kontur merupakan sebuah pelengkap pendeteksi warna, dimana ketika warna sudah terdeteksi, kontur akan segera mengelilingi wilayah warna yang terdeteksi tersebut dengan bentuk kotak (rectangle). Bentuk kontur berupa kotak (rectangle) diperoleh melalui algoritma yang berisi point-point pembentuk kontur.

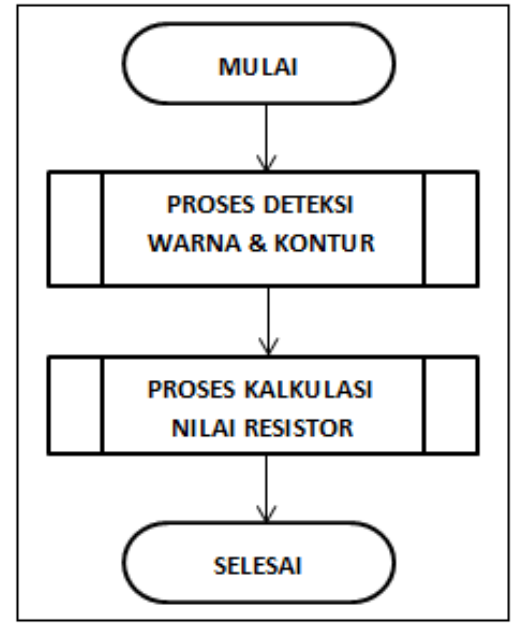

Gambar 1 Blok diagram sistem keseluruhan

Pada proses ini merupakan tahap akhir dari semua proses pendeteksian terhadap resistor. Untuk mendukung proses perhitungan atau kalkulasi pada layar antarmuka dibuat sebuah tempat khusus untuk proses kalkulasi, berupa 3 buah spinner yang mewakili 3 gelang resistor. Dapat dilihat pada Gambar 2 dari sini user dapat langsung melakukan konfirmasi warna-warna yang terdeteksi dengan langsung menekan tombol pilih yang terletak pada masingmasing spinner yang mewakili masing-masing gelang warna. Ketika proses perhitungan sudah selesai, maka hasil nilai resistor dapat langsung diketahui dalam bentuk toast yaitu sebuah notifikasi yang muncul beberapa saat di layar antarmuka.

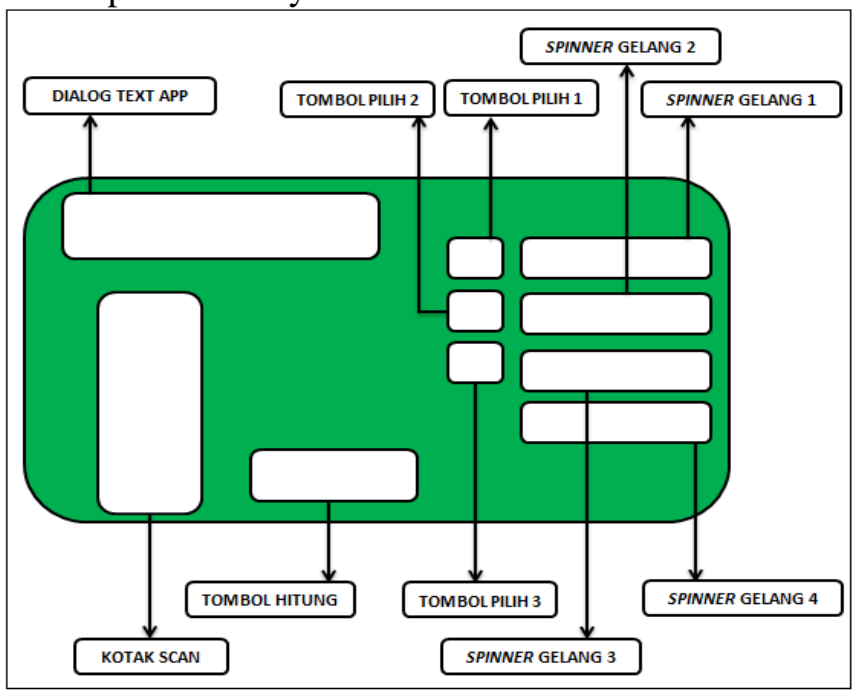

Gambar 2 Desain antarmuka sistem 


\subsection{Implementasi Perangkat Keras Sistem}

Implementasi perangkat keras pada sistem pemindai resistor ini terdiri dari tiga bagian yaitu :

\subsubsection{Implementasi Resistor dan Handphone Android}

Resistor yang digunakan adalah resistor yang berukuran $1 / 2$ Watt, 1 Watt dan 2 Watt yang ditempatkan di sebuah meja yang beralaskan kertas HVS putih sebagai wadah pendeteksian. Untuk jarak pendeteksian antara kamera dan resistor dibatasi dengan tinggi kamera maksimal $30 \mathrm{~cm}$ diukur dari permukaan meja.

\subsubsection{Implementasi Light Meter dan Lampu Dimmer}

Light Meter yang digunakan adalah Light Meter Lutron LX-100. Light Meter ditempatkan tepat disamping tempat. Untuk lampu dimmer digunakan lampu 8 Watt. Yang diletakkan pada fitting lampu pada jarak $30 \mathrm{~cm}$ dari permukaan meja.

\subsubsection{Implementasi Perangkat Keras Secara Keseluruhan}

Secara keseluruhan, semua perangkat keras ditempatkan pada sebuah ruangan yang hanya memiliki satu sumber penerangan saja yaitu lampu dimmer. Lampu dimmer diletakkan di atas meja dan diatur ketinggian lampu setinggi $30 \mathrm{~cm}$ yang diukur dari permukaan meja. Kemudian Light Meter diletakkan tepat dibawah lampu dimmer, selanjutnya adalah resistor diletakkan di atas meja yang beralaskan kertas HVS putih tepat dibawah lampu dimmer.

\subsection{Implementasi Perangkat Lunak Sistem}

Pada bagian ini akan dibahas mengenai implementasi perangkat lunak pada pengolahan citra digital. Dalam pemrograman digunakan Eclipse IDE yang merupakan open source, Eclipse IDE mendukung beberapa pemrograman bahasa. Penelitian ini menggunakan bahasa Java dan XML sebagai bahasa pemrograman utama dalam aplikasi ini. Bahasa pemrograman Java digunakan untuk memprogram seluruh logika pemrograman, pengolahan citra dan prosesproses utama lainnya. Sedangkan bahasa XML digunakan untuk membuat desain layout antarmuka sistem. Dalam pemrograman digunakan pustaka dari OpenCV yaitu OpenCV Library For Android yang berisi berbagai macam fungsi-fungsi pemrograman OpenCV khususnya image processing yang dapat diintegrasikan ke dalam Eclipse IDE. Bentuk antarmuka sistem dapat dilihat pada Gambar 3.

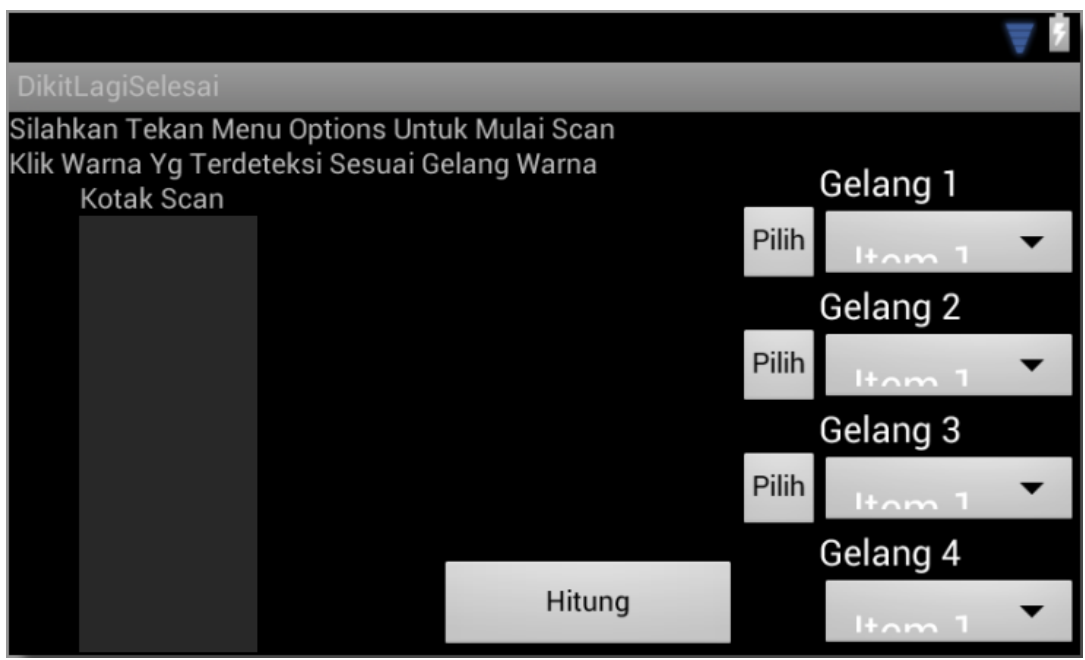

Gambar 3 Antarmuka sistem

IJEIS Vol. 5, No. 1, April 2015 : 1 - 10 


\section{HASIL DAN PEMBAHASAN}

Pada sistem ini dilakukan 2 macam pengujian, yaitu pengujian terhadap intensitas cahaya dan pengujian terhadap jarak antara kamera dan objek gelang warna resistor.

Untuk mendeteksi warna resistor dilakukan dengan menggunakan seleksi warna model HSV. Pada aplikasi pengenalan objek warna diberikan nilai batas ambang atas dan bawah nilainilai hue, saturate dan value pada suatu warna.[5] Pemberian batas ambang terhadap warna dapat dilihat pada Tabel 1.

Tabel 1 Batas ambang nilai HSV

\begin{tabular}{|l|c|c|c|c|c|c|c|}
\hline \multirow{2}{*}{ No } & \multirow{2}{*}{ Warna } & \multicolumn{2}{|c|}{ Hue } & \multicolumn{2}{c|}{ Saturation } & \multicolumn{2}{c|}{ Value } \\
\cline { 3 - 8 } & & $\begin{array}{c}\text { Batas } \\
\text { Atas }\end{array}$ & $\begin{array}{c}\text { Batas } \\
\text { Bawah }\end{array}$ & $\begin{array}{c}\text { Batas } \\
\text { Atas }\end{array}$ & $\begin{array}{c}\text { Batas } \\
\text { Bawah }\end{array}$ & $\begin{array}{c}\text { Batas } \\
\text { Atas }\end{array}$ & $\begin{array}{c}\text { Batas } \\
\text { Bawah }\end{array}$ \\
\hline 1 & Hitam & 4 & 16 & 30 & 7 & 30 & 75 \\
\hline 2 & Coklat & 22 & 106 & 53 & 60 & 180 & 106 \\
\hline 3 & Merah & 170 & 160 & 60 & 180 & 255 & 255 \\
\hline 4 & Jingga & 18 & 40 & 90 & 22 & 255 & 255 \\
\hline 5 & Kuning & 22 & 100 & 100 & 38 & 255 & 255 \\
\hline 6 & Hijau & 40 & 100 & 100 & 75 & 255 & 255 \\
\hline 7 & Biru & 100 & 100 & 100 & 120 & 255 & 255 \\
\hline 8 & Ungu & 128 & 80 & 80 & 155 & 210 & 210 \\
\hline 9 & Abu-Abu & 20 & 0 & 100 & 50 & 35 & 200 \\
\hline 10 & Putih & 20 & 0 & 225 & 50 & 35 & 255 \\
\hline 11 & Emas & 20 & 106 & 53 & 20 & 78 & 50 \\
\hline 12 & Perak & 170 & 65 & 95 & 175 & 71 & 100 \\
\hline
\end{tabular}

\subsection{Pengujian Pengaruh Intensitas Cahaya}

Intensitas cahaya memiliki pengaruh yang besar terhadap pengolahan citra. Besar kecilnya intensitas cahaya akan mempengaruhi kinerja dari kamera handphone sebagai alat yang digunakan untuk menangkap citra.[6] Ketika gelang warna resistor dikenakan intensitas cahaya yang besar, maka kamera handphone akan menangkap gelang warna resistor yang terlalu terang atau silau, sedangkan jika intensitas cahaya yang diberikan terlalu kecil maka kamera handphone akan menangkap gelang warna resistor yang terlalu gelap. Dalam pengolahan citra intensitas cahaya yang terlalu besar atau terlalu kecil dapat mengakibatkan objek yang ingin diteliti tidak terdeteksi dan dapat menghasilkan derau sehingga proses identifikasi objek dengan cara segmentasi warna akan terganggu.[7]

Pengujian ini dilakukan untuk mengetahui besar dan kecil nilai intensitas cahaya agar kamera handphone dapat mendeteksi warna gelang resistor. Pengujian dilakukan didalam ruangan dengan sumber cahaya dari lampu dimmer. Hasil yang diharapkan yaitu berupa respon terhadap perubahan cahaya. Variabel yang digunakan yaitu lampu Panasonic $8 \mathrm{~W}$ yang divariasi gelap terangnya menggunakan lampu dimmer.

Pengujian dilakukan sebanyak 10 kali dengan memberikan 10 buah sampel resistor dengan nilai yang berbeda-beda sehingga data yang akan diambil nantinya adalah kesesuaian antara nilai resistor dengan hasil pembacaan oleh sistem. Untuk mengetahui hasil keakuratan pembacaan sistem dinyatakan dalam $0 \%$ (tidak terdeteksi), 50\% (terdeksi sebagian) dan $100 \%$ (terdeteksi dengan baik). 
Tabel 2 Hasil pengujian pengaruh intensitas cahay pada semua warna gelang resistor (Resistor Ukuran $1 / 2$ Watt)

\begin{tabular}{|c|c|c|}
\hline NO & $\begin{array}{c}\text { Nilai } \\
\text { Kecerahan (lux) }\end{array}$ & $\begin{array}{c}\text { Keakuratan } \\
\text { Pembacaan Sistem }\end{array}$ \\
\hline 1 & 0 & $0 \%$ \\
\hline 2 & 50 & $0 \%$ \\
\hline 3 & 200 & $50 \%$ \\
\hline 4 & 400 & $50 \%$ \\
\hline 5 & 600 & $100 \%$ \\
\hline 6 & 800 & $100 \%$ \\
\hline 7 & 1000 & $100 \%$ \\
\hline 8 & 1200 & $100 \%$ \\
\hline 9 & 1400 & $50 \%$ \\
\hline 10 & 1500 & $50 \%$ \\
\hline
\end{tabular}

Tabel 2 adalah tabel hasil pengujian rata-rata pengaruh intensitas cahaya pada semua warna gelang resistor terhadap objek yaitu gelang warna resistor yang berukuran $1 / 2$ watt. Kondisi pencahayaan divariasi dari 0 lux (kondisi sangat gelap) hingga 1500 (kondisi sangat terang). Pengujian terhadap masing-masing warna dilakukan untuk mengetahui respon masingmasing warna terhadap perubahan cahaya. Hal ini berdasarkan karena masing-masing warna mempunyai panjang gelombang yang berbeda-beda sehingga diperlukan pengujian dan analisa yang dilakukan pada masing-masing warna.

Setelah semua data telah diperoleh, maka selanjutnya dilakukan pengambilan hasil pengujian rata-rata pengaruh intensitas cahaya pada semua warna. Pengambilan hasil pengujian ini dilakukan untuk mengetahui intensitas cahaya yang optimal terhadap sistem dapat mendeteksi dengan baik gelang warna resistor. Pada kondisi gelap yaitu sekitar 0-50 lux, citra tidak dapat ditangkap oleh kamera handphone, sehingga objek warna gelang resistor tidak dapat dideteksi.

Pada kondisi ke-3 yaitu dengan intensitas cahaya sekitar 200 lux, ada beberapa warna yang dapat dideteksi dan ada sebagian warna yang tidak dapat terdeteksi, sehingga proses pendeteksian warna menjadi tidak sempurna. Pada kondisi ke-5. Ke-6, ke-7 dan ke-8 saat intensitas cahaya sekitar 600-1200 lux, proses pendeteksian warna terdeteksi sempurna hal ini ditandai dengan semua warna dapat dikenali dengan baik pada intensitas 600-1200 lux. Pada kondisi ke-9 dan ke-10 saat intensitas cahaya bernilai 1400-1500 lux terjadi penurunan pendeteksian hal ini diakibatkan oleh beberapa warna yang tidak dapat terdeteksi karena terlalu silau atau terang sehingga mempengaruhi proses pendeteksian warna.

Pada Tabel 3 dan Tabel 4 Pada kondisi ke-3 yaitu dengan intensitas cahaya sekitar 200 lux, ada beberapa warna yang dapat dideteksi dan ada sebagian warna yang tidak dapat terdeteksi, sehingga proses pendeteksian warna menjadi tidak sempurna.

Pada kondisi ke-4, ke-5. Ke-6, ke-7 dan ke-8 saat intensitas cahaya sekitar 400-1200 lux, proses pendeteksian warna terdeteksi sempurna hal ini ditandai dengan semua warna dapat dikenali dengan baik pada intensitas 400-1200 lux. Pada kondisi ke-9 dan ke-10 saat intensitas cahaya bernilai 1400-1500 lux terjadi penurunan pendeteksian hal ini diakibatkan oleh beberapa warna yang tidak dapat terdeteksi karena terlalu silau atau terang sehingga mempengaruhi proses pendeteksian warna.

IJEIS Vol. 5, No. 1, April 2015 : 1 - 10 
Tabel 3 Hasil pengujian pengaruh intensitas cahay pada semua warna gelang resistor (Resistor Ukuran 1 Watt)

\begin{tabular}{|c|c|c|}
\hline NO & $\begin{array}{c}\text { Nilai } \\
\text { Kecerahan (lux) }\end{array}$ & $\begin{array}{c}\text { Keakuratan } \\
\text { Pembacaan Sistem }\end{array}$ \\
\hline 1 & 0 & $0 \%$ \\
\hline 2 & 50 & $0 \%$ \\
\hline 3 & 200 & $50 \%$ \\
\hline 4 & 400 & $100 \%$ \\
\hline 5 & 600 & $100 \%$ \\
\hline 6 & 800 & $100 \%$ \\
\hline 7 & 1000 & $100 \%$ \\
\hline 8 & 1200 & $100 \%$ \\
\hline 9 & 1400 & $50 \%$ \\
\hline 10 & 1500 & $50 \%$ \\
\hline
\end{tabular}

Tabel 4 Hasil pengujian engaruh intensitas cahaya pada semua warna gelang resistor (Resistor Ukuran 2 Watt)

\begin{tabular}{|c|c|c|}
\hline NO & $\begin{array}{c}\text { Nilai } \\
\text { Kecerahan (lux) }\end{array}$ & $\begin{array}{c}\text { Keakuratan } \\
\text { Pembacaan Sistem }\end{array}$ \\
\hline 1 & 0 & $0 \%$ \\
\hline 2 & 50 & $0 \%$ \\
\hline 3 & 200 & $50 \%$ \\
\hline 4 & 400 & $100 \%$ \\
\hline 5 & 600 & $100 \%$ \\
\hline 6 & 800 & $100 \%$ \\
\hline 7 & 1000 & $100 \%$ \\
\hline 8 & 1200 & $100 \%$ \\
\hline 9 & 1400 & $50 \%$ \\
\hline 10 & 1500 & $50 \%$ \\
\hline
\end{tabular}

Dari hasil pengujian, secara keseluruhan intensitas cahaya yang tepat untuk melakukan pendeteksian gelang warna resistor ini adalah pada 400 lux hingga 1200 lux dengan ukuran resistor 1 Watt dan 2 Watt.

\subsection{Pengujian Pengaruh Jarak Pendeteksian}

Proses pendeteksian sangat berpengaruh terhadap jarak pendeteksian. Proses pendeteksian yang dilakukan adalah dengan mengarahkan kamera tepat terhadap resistor secara tegak lurus. Jarak pendeteksian yang dilakukan adalah jarak pendeteksian antar kamera dan objek gelang warna resistor. Oleh karena itu diperlukan pengujian terhadap jarak dengan intensitas cahaya yang tepat untuk pendeteksian warna yaitu 400-1200 lux. 
Tabel 5 Hasil Pengujian Jarak Antar Kamera dan Resistor

\begin{tabular}{|c|c|c|}
\hline No & $\begin{array}{c}\text { Jarak Kamera } \\
\text { Handphone Ke Resistor (cm) }\end{array}$ & $\begin{array}{c}\text { Hasil Pendeteksian } \\
\text { Objek Warna Gelang } \\
\text { Resistor }\end{array}$ \\
\hline 1 & 5 & $100 \%$ \\
\hline 2 & 10 & $100 \%$ \\
\hline 3 & 15 & $100 \%$ \\
\hline 4 & 20 & $100 \%$ \\
\hline 5 & 25 & $50 \%$ \\
\hline 6 & 30 & $0 \%$ \\
\hline 7 & 35 & $0 \%$ \\
\hline
\end{tabular}

Dari Tabel 5 merupakan hasil pengujian jarak antar kamera dan resistor. Dari tabel tersebut dapat dilihat bahwa pada jarak $5 \mathrm{~cm}, 10 \mathrm{~cm}, 15 \mathrm{~cm}$, dan $20 \mathrm{~cm}$ kamera dapat mendeteksi gelang warna resistor dengan baik. Ketika jarak divariasikan menjadi $25 \mathrm{~cm}$ hanya beberapa warna yang bisa dideteksi, hal ini diakibatkan masing-masing warna mempunyai panjang gelombang yang berbeda-beda sehingga proses pendeteksian menjadi tidak sempurna. Pada jarak $30 \mathrm{~cm}$ dan $35 \mathrm{~cm}$ gelang warna resistor tidak terdeteksi hal ini diakibatkan ukuran gelang warna resistor yang kecil sehingga kamera tidak mampu mendeteksi objek gelang warna resistor. Dengan demikian, dari hasil pengujian secara keseluruhan jarak pendeteksian yang tepat untuk melakukan pendeteksian warna gelang resistor ini adalah pada jarak maksimal $20 \mathrm{~cm}$ antar kamera dan resistor.

Tabel 6 Hasil Pengujian Pengaruh Intensitas dan jarak Optimal Pada Resistor (1/2 Watt)

\begin{tabular}{|c|c|c|c|}
\hline No & $\begin{array}{l}\text { Nilai Resistor } \\
(\Omega)\end{array}$ & $\begin{array}{c}\text { Hasil } \\
\text { Pendeteksian Sistem ( }(\Omega)\end{array}$ & $\begin{array}{c}\text { Keakuratan } \\
\text { Pembacaan } \\
\text { Sistem } \\
\end{array}$ \\
\hline 1 & $33 \Omega$ & $33 \Omega$ & $100 \%$ \\
\hline 2 & $56 \Omega$ & $56 \Omega$ & $100 \%$ \\
\hline 3 & $110 \mathrm{~K} \Omega$ & $110 \mathrm{~K} \Omega$ & $100 \%$ \\
\hline 4 & $22 \mathrm{~K} \Omega$ & $22 \mathrm{~K} \Omega$ & $100 \%$ \\
\hline 5 & $27 \Omega$ & $27 \Omega$ & $100 \%$ \\
\hline 6 & $47 \mathrm{~K} \Omega$ & $47 \mathrm{~K} \Omega$ & $100 \%$ \\
\hline 7 & $51 \Omega$ & $51 \Omega$ & $100 \%$ \\
\hline 8 & $36 \mathrm{~K} \Omega$ & $36 \mathrm{~K} \Omega$ & $100 \%$ \\
\hline 9 & $1,3 \mathrm{~K} \Omega$ & $1,3 \mathrm{~K} \Omega$ & $100 \%$ \\
\hline 10 & $1,5 \Omega$ & $1,5 \Omega$ & $100 \%$ \\
\hline
\end{tabular}

Tabel 7 Hasil Pengujian Pengaruh Intensitas dan jarak Optimal Pada Resistor (1 Watt)

\begin{tabular}{|c|c|c|c|}
\hline No & $\begin{array}{l}\text { Nilai Resistor } \\
(\Omega)\end{array}$ & $\begin{array}{c}\text { Hasil } \\
\text { Pendeteksian Sistem }(\Omega)\end{array}$ & $\begin{array}{c}\text { Keakuratan } \\
\text { Pembacaan } \\
\text { Sistem }\end{array}$ \\
\hline 1 & $1 \mathrm{~K} \Omega$ & $1 \mathrm{~K} \Omega$ & $100 \%$ \\
\hline 2 & $560 \Omega$ & $560 \Omega$ & $100 \%$ \\
\hline 3 & $390 \Omega$ & $390 \Omega$ & $100 \%$ \\
\hline 4 & $470 \Omega$ & $470 \Omega$ & $100 \%$ \\
\hline 5 & $510 \Omega$ & $510 \Omega$ & $100 \%$ \\
\hline 6 & $2,7 \mathrm{~K} \Omega$ & $2,7 \mathrm{~K} \Omega$ & $100 \%$ \\
\hline 7 & $10 \mathrm{~K} \Omega$ & $10 \mathrm{~K} \Omega$ & $100 \%$ \\
\hline 8 & $3,3 \mathrm{~K} \Omega$ & $3,3 \mathrm{~K} \Omega$ & $100 \%$ \\
\hline 9 & $27 \mathrm{~K} \Omega$ & $27 \mathrm{~K} \Omega$ & $100 \%$ \\
\hline 10 & $3 \mathrm{~K} \Omega$ & $3 \mathrm{~K} \Omega$ & $100 \%$ \\
\hline
\end{tabular}

Pada Tabel 6, Tabel 7 dan Tabel 8 merupakan hasil pengujian dengan 10 sampel resistor dengan nilai resistor yang berbeda pada jarak dan intensitas yang optimal yaitu dengan intensitas 400-1200 lux dan jarak maksimal $20 \mathrm{~cm}$. Pengujian ini dilakukan untuk mengetahui hasil pengukuran yang dilakukan oleh sistem pemindai berdasarkan nilai resistor yang 
sebenarnya. Dari hasil pengujian ini dapat disimpulkan bahwa hasil pengukuran yang dilakukan oleh sistem sama dengan nilai resistor. Hal ini ditandai dengan angka hasil pengukuran yang sama yang mengindikasikan bahwa warna yang terdapat pada gelang resistor dapat dideteksi dengan baik.

Tabel 8 Hasil Pengujian Pengaruh Intensitas dan jarak Optimal Pada Resistor (2 Watt)

\begin{tabular}{|l|c|c|c|}
\hline No & $\begin{array}{c}\text { Nilai Resistor } \\
(\boldsymbol{\Omega})\end{array}$ & $\begin{array}{c}\text { Hasil } \\
\text { Pendeteksian Sistem }(\boldsymbol{\Omega})\end{array}$ & $\begin{array}{c}\text { Keakuratan } \\
\text { Pembacaan Sistem }\end{array}$ \\
\hline 1 & $270 \mathrm{~K} \Omega$ & $270 \mathrm{~K} \Omega$ & $100 \%$ \\
\hline 2 & $4,3 \mathrm{~K} \Omega$ & $4,3 \mathrm{~K} \Omega$ & $100 \%$ \\
\hline 3 & $1,5 \Omega$ & $1,5 \Omega$ & $100 \%$ \\
\hline 4 & $330 \mathrm{~K} \Omega$ & $330 \mathrm{~K} \Omega$ & $100 \%$ \\
\hline 5 & $30 \mathrm{~K} \Omega$ & $30 \mathrm{~K} \Omega$ & $100 \%$ \\
\hline 6 & $220 \Omega$ & $220 \Omega$ & $100 \%$ \\
\hline 7 & $47 \Omega$ & $47 \Omega$ & $100 \%$ \\
\hline 8 & $56 \mathrm{~K} \Omega$ & $56 \mathrm{~K} \Omega$ & $100 \%$ \\
\hline 9 & $27 \mathrm{~K} \Omega$ & $27 \mathrm{~K} \Omega$ & $100 \%$ \\
\hline 10 & $560 \mathrm{~K} \Omega$ & $560 \mathrm{~K} \Omega$ & $100 \%$ \\
\hline
\end{tabular}

\section{KESIMPULAN}

1. Telah berhasil diimplementasikan pengolahan citra digital sebagai pengukur nilai resistor pada sistem pemindai resistor berbasis android.

2. Sistem mampu mendeteksi gelang-gelang warna resistor dengan baik.

3. Kinerja sistem paling baik didapatkan pada kondisi lingkungan dengan intensitas cahaya ruangan 400 lux hingga 1200 lux dengan jarak antar kamera dan resistor maksimal $20 \mathrm{~cm}$.

\section{SARAN}

1. Hendaknya proses pembacaan resistor dilakukan secara serentak tidak mendeteksi satupersatu gelang warna resistor.

2. Hendaknya dapat diintegrasikan pada device yang memiliki spesifikasi yang lebih baik.

\section{DAFTAR PUSTAKA}

[1] Usman, A. (2005). Pengolahan Citra Digital. Graha Ilmu, Yogyakarta.

[2] Hariyanto, 2009, Studi Penentuan Warna Menggunakan HSI, http://www.google.com/url?sa=t\&rct=j\&q=\&esrc=s\&source=web\&cd=1\&cad=rja\&ved $=0 \mathrm{CCoQFjAA \& url=http} \% 3 \mathrm{~A} \% 2 \mathrm{~F} \% 2 \mathrm{Ftelkomnika}$ ee. uad.ac.id\%2Fn9\%2Ffiles\%2FVol. 7No.1Apr09\%2F7.1.4.09.02.pdf\&ei=WddsUs7 K5DkrAfNuYDwBw\&usg=AFQjCNFI Gq9ex1p1ehyDLSHzFbO7MG8P2Q\&sig2=w8pQmuGpaRDsczywhxft7Q\&bvm=bv.55 123115,d.bmk, diakses pada 23 April 2013.

[3] Luijten, H.J.C, 2005, Basic of Color Based Computer Vision Implemented in Matlab, Technische Universiteit Eindhoven.

[4] Gonzalez, Rafael, C., Woods, Richard, E., Eddins, Steven, L., (2004). Digital Image Processing. Prentice Hall. 
[5] Shahid, A.M., 2012, Purwarupa Sistem Pendeteksi Garis landasan Pacu Berdasar Pengolahan Citra, Skripsi Elektronika dan Instrumentasi, Fakultas MIPA, Universitas Gadjah Mada.

[6] Erwhin, I. 2013, Implementasi Pengolahan Citra Digital Sebagai Pengukur Tinggi Badan Pada Sistem Pengukur Keidealan Badan, Skripsi Elektronika dan Instrumentasi, Fakultas MIPA, Universitas Gadjah Mada.

[7] Simanjuntak, F., 2009. Pengolahan Citra Digital, http://digilib.ittelkom.ac.id/index.php?option=com_content\&view=article\&id=573:pen golahan-citra-digital\&catid=15:pemrosesan-sinyal\&Itemid=14, diakses pada 18 Mei 2013.

IJEIS Vol. 5, No. 1, April 2015 : 1 - 10 